tively-owned factories that allowed them to maintain an industrial niche where craft skills and work traditions were preserved for nearly a generation. In doing so, they left a lasting imprint on the occupational, political, religious, musical, recreational, and community life of northern West Virginia - helping to build a transnational culture that challenges the simplistic stereotype of West Virginia and Appalachia as a culturally homogeneous place where time stood still.

Ken Fones-Wolf has written a fine, provocative and iconoclastic book that merits the most serious attention. It encourages a rethinking of glass-making on both sides of the Atlantic and a much needed reappraisal of the making of one of America's most interesting and perplexing regions.

Dwight B. Billings

\title{
Wildt, Michael. Volksgemeinschaft als Selbstermächtigung. Gewalt gegen Juden in der deutschen Provinz 1919 bis 1939. Hamburger Edition, Hamburg 2007, 432 pp. € 28.00.DOI: 10.1017/S0020859008063463
}

Michael Wildt begins his book with the "dense description" of a photograph. During a lazy sunny Sunday afternoon on I9 August 1933 in Marburg, a man in a dark suit is walking with a picket sign which reads: "I have violated a Christian girl". A closer look reveals that this man was forced to march between columns of SA brownshirts. It was a sight to see for a crowd of onlookers: a middle-aged woman with a young baby in her arms, a lady shading her eyes against the sun with her right hand, a plump lady saluting the SA columns by way of a "German greeting" with her right hand held high, poker-faced bystanders, a young lad on a bicycle following the march, and cheering young lads who are curiosity-seekers by nature. But it is difficult to catch what these spectators were actually thinking deep in their hearts. This book can be read as an Alltagsgeschichte historian's challenge to this defying issue.

Wildt argues that these public actions of humiliating Jews could be successful only when bystanders, though reluctant and not yet really convinced, were involved and transformed into silent accomplices. It is these spectators who filled the seemingly boring SA march in the lazy sunny Sunday afternoon with historical meaning. It is at this point that bystanders become silent accomplices to the anti-Semitic politics, even though they might not be the perpetrators. But Wildt is critical of the "totalizing consequence" of identifying German society between I933 and 1945 as the "perpetrators' society" as a whole. In his book, the moralist conception of "perpetrators" is replaced by the complex reality of "actors" as historical agents.

The focus on historical agents leads Wildt to explore how ordinary people participated and engaged in the process of making a racist "national community" (Volksgemeinschaft) and how the violent, exclusionary anti-Semitic everyday praxis among ordinary people transformed the German nation. The ordinary people cease to be passive objects of the regime's propaganda, mobilization, and political engineering. Rather, the people appear on the historical horizon as active subjects who try to seize any opportunity for their own cause. The title of his book, which can be translated as "national community as selfempowerment", implies the author's focus on ordinary people as active agents.

Anchored in the neo-Marxism of the New Left, the "history from below" of the Third Reich was initially pregnant with optimistic assumptions about the self-activity and 
emancipatory capacity of the working class. The thesis on what the "working class should have been like" confronted more complex realities. Especially in the I990s after the "Fall", however, the "history from below" of the Third Reich witnessed a sudden shift in focus from resistance to consent/consensus. For traditional left-wing historians it is a very perplexing revelation that the working class für sich gave their consent to the fascist regime. That is why some stubborn left-wing historians branded this shift as a sort of political defeatism and historical masochism. For its emphasis on mass participation in and support for dictatorial regimes, my own thesis of "mass dictatorship" has suffered from a similar misunderstanding among Korean left-wing intellectuals.

I would like to call this shift the self-reflexive turn of "history from below" which notices that the dividing line between good and evil, victims and perpetrators, does not run clearly between "them" and "us" but through each individual. Historical agents are not predestined politically. Individuals meander between self-empowerment and selfmobilization through historical moments. Thus, any viable explanation will be multilinear rather than uni-linear, pluralist rather than dualist, and ambiguous rather than unambiguous. So, dualistic terms of "coercion and consent" and "resistance and collaboration" are deconstructed and pluralized.

The self-reflexive turn is where Wildt's book stands. Viewed from below, the diametric opposition between intentionalist and structuralist interpretation melts away. Two conflicting interpretations are embedded in the same historiographical matrix of "history from above", which regards the state decrees, operations, and orders as the main factors. What is in question is not just the anti-Semitism of state racism but the everyday praxis of social anti-Semitism. Furthermore, Wildt's "history from below" differs from that of Daniel Goldhagen, who presumes Volksgemeinschaft as a given "a priori” in German society. Wildt stresses the transformation of German society into the Volksgemeinschaft by the violent participation of the masses from below. He is in search of the ordinary people's everyday praxis of violence which contributed much to the making of the Volksgemeinschaft. Villages and small towns in rural areas seem a reasonable choice, because their face-to-face society milieu makes their intimate everyday lives tangible.

Viewed from another perspective, the semantics of the Volksgemeinschaft also influenced how ordinary Germans perceived reality and thus their everyday praxis. Volksgemeinschaft as a promise to fulfil the longing for identity, power, and sovereignty was shared by both left and right in interwar Germany. If, as Ernest Gellner argues, "nationalism is a phenomenon of Gesellschaft using the idiom of Gemeinschaft", then nationalist politics of inclusion/exclusion was inherent to the Volksgemeinschaft. Once connected with the idea of people's sovereignty, the racist Volksgemeinschaft acquires legitimacy beyond the German Constitution. The people's will as the "constituent power" is not subject to laws and has in fact the legislative power to make its own constitution. It can desire whatever it pleases because its desire equals constitutional power. Carl Schmitt's remark that "fascism is anti-liberal but not necessarily anti-democratic" represents the legitimatization of fascism.

Volksgemeinschaft was not a pre-modern but a modern construct. In his book The Nationalization of the Masses, ${ }^{\mathrm{I}}$ Mosse made it explicit that "fascist style was in reality the climax of a 'new politics' based on the emerging eighteenth-century idea of popular sovereignty". More recently, Hardt and Negri revealed the magic of making fascism democratic at the moment when the feudal order of the subject yielded to the disciplinary

I. George Mosse, The Nationalization of the Masses (New York, 1975). 
order of the citizen. ${ }^{2}$ Most recently, Mann has warned of the potential danger of democracy when the majority tyrannizes minorities, especially in certain multi-ethnic environments. ${ }^{3}$ The spectre of Carl Schmitt still haunts us when we learn that Hutus massacred Tutsis under the slogan of "majoritarian democracy".

Volksgenosse (national comrades) signified the shift of the population from passive subjects to active citizens. Wildt's deliberate usage of the term Mitmachen (participator) instead of Komplizit (accomplices) seems to touch on this point. Insofar as they are not identified as "anti-socials", "strangers to community", and the "enemy of the community", the national comrades of the Volksgemeinschaft had nothing to fear. Perhaps the national comrades felt obliged to prove that they were complying with the Volksgemeinschaft through violent actions against the excluded castes. Citing Alf Lüdtke, Wildt writes that violent action from below was a "political form of compliance" and "acting subjects took part in the political domination in their own ways".

The examples of violent action are too many to be enumerated here. The customers of Jewish shops were photographed, and these photographs, often accompanied by the full addresses of the people shown, were publicly displayed in the Stürmer-Kästen (large red display cases found in almost every German town, in which the latest issues of the antiSemitic periodical Stürmer were posted). In Köthen, a town in Saxony, the mayor called in riot police to disperse the crowd in an anti-Semitic riot. Many an image of Rassenschande (literally, racial shame) shows crowds jeering at their victims, around whose necks were hung obscene slogans. As time went by, more and more young people took part in campaigns to boycott Jewish businesses. In particular, schoolboys or members of the Hitler Youth shouting anti-Semitic slogans stood guard in front of Jewish shops and prevented customers from shopping there.

Very often, voluntary action from below overwhelmed the Nazi Party's manipulative initiative. The local authority had to succumb to the intense pressure from below and tried to check the violence of this voluntary action, but in vain. Many photographs show large numbers of people in civilian clothes, different from the uniformed Nazi Party members. A SOPADE report from January 1936 stated that anti-Semitism had rooted deeply in most circles of German society. Even social democrats, who clearly objected to the violent attacks, were in favour of ending alleged Jewish supremacy, once and for all, and of restricting the Jews to certain spheres of activity. It is not easy, of course, to say whether the people were enthusiastic perpetrators, active participants, or passive bystanders. But Wildt notes that these violent attacks took place in public without any serious intervention. He reads into this a consensus among ordinary Germans that the law could be suspended to the detriment of their excommunicated Jewish neighbours.

All the merits and attractions of Wildt's book cannot fail to overcome my concern about one point. We still lack the inner world of any one specific individual. The self-reflexive turn of "history from below" by Michael Wildt might be more persuasive when backed by a micro-historical approach such as that in Carlo Ginzburg's The Cheese and the Worms. ${ }^{4}$ Can we expect a reconstruction of the cosmos of a German Menocchio in the Third Reich in the near future? One hopes so.

2. Michael Hardt and Antonio Negri, Empire (London, 2000).

3. Michael Mann, The Dark Side of Democracy (Cambridge, 2005).

4. Carlo Ginzburg, The Cheese and the Worms (London, I980). 